\title{
Corporeidade e violações de direitos humanos: saúde e testemunho
}

\author{
Eduardo Passos, ${ }^{\star}$ Cristina Rauter \\ Universidade Federal Fluminense, Niterói, RJ, Brasil
}

\begin{abstract}
Resumo
Uma reflexão a partir da experiência profissional dos autores como coterapeutas de um grupo, realizado enquanto membros da Equipe Clínico-Grupal Tortura Nunca Mais do Rio de Janeiro. Partindo de uma abordagem na qual a corporeidade é tomada como dimensão fundamental da experiência da violência, abordamos a especificidade da violência praticada por agentes do Estado em suas dimensões ético-estético-políticas. Os efeitos singulares da violência praticada pelo Estado são analisados, construindo-se uma certa concepção de saúde que corresponde à reconexão com o coletivo e com o resgate histórico das lutas de um povo. Na construção dessa abordagem trabalhamos com conceitos das filosofias de Spinoza, Bergson e Merleau-Ponty numa perspectiva transdisciplinar.
\end{abstract}

Palavras-chave: corporeidade; violência do Estado; clínica transdisciplinar.

\section{Corporeity and human rights violations: health and testimony}

\begin{abstract}
A reflection on the professional experience of the authors as cotherapists of a group while members of the Tortura Nunca Mais of Rio de Janeiro Clinical Staff. Departing from Corporeity as a fundamental dimension of the experience of violence, we focus upon the specific character of violence when perpetrated by the State in its ethical-esthetical-political dimensions. The singular effects of the violence practiced by the State are analyzed, building a certain conception of health which corresponds to reconnection with collective experience and with the historical rescue of the struggle of a people. In the construction of this perspective, we have worked with concepts of the philosophies of Spinoza, Bergson and Merleau-Ponty in a transdisciplinary perspective.
\end{abstract}

Keywords: corporeity; State violence; transdisciplinary clinics.

A experiência clínica que adquirimos ao longo de mais de uma década atendendo aos atingidos pela tortura e outras violações de direitos humanos como membros da Equipe Clínico Grupal Tortura Nunca Mais-RJ (GTNM) é objeto de nossa reflexão neste artigo.

A luta pelo esclarecimento e responsabilização por crimes de lesa humanidade praticados durante a ditadura militar brasileira ainda continua no Brasil. O mesmo ocorre em relação aos assassinatos de jovens negros praticados por agentes do Estado diariamente. Recentemente soubemos da anulação do processo que pedia a condenação dos responsáveis pelo conhecido Massacre do Carandiru, no qual mais de 100 presos desarmados foram exterminados por policiais há mais de uma década. As justificativas para seguir lutando pelo esclarecimento e responsabilização por esses crimes dizem respeito a razões éticas e políticas. É preciso retomar Guattari em sua insistência na construção de um paradigma éticoestético-político para a clínica (GUATTARI, 1990), desse modo incluindo e enfatizando neste artigo um ponto de vista clínico-político para essa luta.

Para muitos, a punição pela pena de prisão dos culpados é o objetivo do esclarecimento desses crimes. Afinados com o abolicionismo penal, custa-nos propor a prisão como solução, até mesmo nesse caso, ainda que a definição final desse tema não dependa de nossa decisão, mas dos anseios coletivos de toda a sociedade e de providências no âmbito institucional e governamental a serem tomadas. De qualquer modo, apesar do empenho e dos avanços da Comissão da Verdade durante o governo Dilma Rousseff,

\footnotetext{
^Endereço para correspondência: Universidade Federal Fluminense, Departamento de Psicologia Campus do Gragoatá - Bloco O - sala 310 - Gragoatá Rio de Janeiro, RJ - Brasil. CEP: 24000-000. E-mail: e.passos@superig.com. br, rautercristinamair02@gmail.com
}

o Brasil está atrasado em relação a outros países do mundo e até em relação a países latino-americanos no tocante ao esclarecimento oficial desses crimes.

Queremos problematizar nossa experiência como terapeutas de um grupo realizado pelo Projeto ClínicoGrupal Tortura Nunca Mais do Rio de Janeiro do qual éramos integrantes. $\mathrm{O}$ grupo era formado por atingidos direta ou indiretamente pela violência do Estado durante a ditadura civil-militar iniciada em 1964. São considerados atingidos indiretos os familiares dos que foram presos, torturados, mortos ou desaparecidos por ação do Estado. Embora houvesse a especificidade desse pertencimento ao projeto do GTNM, não se tratava propriamente de um grupo terapêutico temático. Não pautávamos a discussão do tema da violência, tampouco incitávamos ao exercício da memória daqueles anos sombrios da história pessoal e coletiva dos integrantes. Como coterapeutas atentos à dimensão clínico-política do sofrimento psíquico, acolhíamos igualmente os relatos que expressavam dificuldades atuais, associadas ou não aos impasses experimentados numa trajetória de vida marcada pela violência institucional e, mais especificamente, pela violência realizada por agentes do Estado.

A violação dos direitos realizada por agentes do Estado não é uma experiência que possa ser pensada sob a designação geral de violência. Há uma especificidade dessas práticas de violação que nos obriga a tomálas como vetores de subjetivação muito singulares e singularizantes, o que pudemos constatar nos anos de trabalho clínico-político com esta população que direta e indiretamente sofreu a força violadora do Estado. 
Vivemos, certamente, num mundo muito violento, no entanto, não é justo considerarmos esse fenômeno sob uma designação genérica que não considere as especificidades das práticas de violação dos direitos humanos. Se há violência por toda parte, há efeitos subjetivos singulares que derivam de formas específicas de violação. Dentre as práticas de violência, aquela realizada por agentes do Estado possui características que não podemos negligenciar em nosso trabalho de atendimento clínico com os atingidos. A violência institucionalizada pelo Estado gera um exponencial do abuso intrínseco a toda forma de violação dos direitos humanos realizada por homens contra homens. O desrespeito ou mesmo a eliminação da diferença entre os homens, a banalização da vida e, sobretudo, a força antidemocrática atinge em seu cerne um povo. É sempre um povo que é ameaçado pelas forças antidemocráticas das práticas da violência que se poderia supor atingir um só indivíduo. Se a violência é um ato contra a democracia e se a democracia é o poder de um povo, é sempre absurdo $\mathrm{o}$ ato de violência realizado pelo povo contra o povo. Se o povo é o conjunto de nós mesmos, o coletivo das pessoas que compõem determinado território, é absurdo que um povo seja atingido pelo ato de violência do povo. Eis o paradoxo da violência que se agrava quando os representantes do povo são agentes do Estado.

A violência realizada por uma instituição encarregada de promover e garantir o bem comum e a salvaguardar a nação produz um efeito de acirramento do absurdo da experiência de ser violentado. $O$ Estado violento atinge violando direitos ao mesmo tempo em que produzindo efeitos de subjetivação que precisam ser avaliados.

Verificamos em nossa prática clínico-política que a violência do Estado produz marcas de sofrimento não só quando mata ou deixa sequelas físicas. Muito frequentemente o niilismo, a depressão, a impotência e a culpa são expressões subjetivas do que, na falta de outro sentido, se apresenta como o trauma da tortura, da prisão, do exílio ou insílio, do desaparecimento ou assassinato de quem se ama.

A prática de violação - e é este o foco de nossa discussão neste texto - sempre implica o corpo do atingido. Não nos parece apropriado dizer que o fenômeno da violência de Estado possa ser considerado a partir da distinção entre tortura física e tortura psicológica, como se pudéssemos supor uma forma de violência que incidisse diretamente sobre a alma dos atingidos sem comprometer necessariamente seu corpo. Toda tortura é sobre um corpo. Toda violência incide sobre uma experiência corpórea. A experiência de ser violentado é uma experiência corpórea de tal maneira que precisamos falar de uma corporeidade atingida. Corroborando essa ideia, sigamos o pressuposto da filosofia de Spinoza, que aponta para a concomitância necessária dos fenômenos da mente e do corpo, de tal forma que tudo o que afeta a mente afeta o corpo e vice-versa, sendo essas duas dimensões da experiência expressões da substância única que nos constitui.
A violência realizada durante a ditadura civil-militar no Brasil não só torturou, matou, fez desaparecer, mas também objetivou produzir um corpo mortificado ao transformar a rebeldia dos revoltosos em culpa ou remorso, a resistência política em resistência à vida, a utopia ativa dos militantes em uma estranha sensação de falta de lugar, de perda de território existencial. Essa é a mortificação de uma experiência corpórea, isto é, não necessariamente marcas físicas como queloides na pele ou órgãos danificados, mas a expressão de corporeidades atingidas pelo absurdo da violência.

Entendemos corporeidade como esta dimensão mais intensiva do que extensiva do corpo. O corpo orgânico, definido por seus esquemas sensório-motores, delimitado pelos seus limites físicos não diz tudo da experiência de ter e ser um corpo que experimenta as forças que sobre ele incidem e que dele advêm. $\mathrm{O}$ corpo intensivo é a experiência da corporeidade, isto é, do corpo lançado no mundo como nave de uma aventura existencial. MerleauPonty (1971) o designou corpo próprio, horizonte existencial sem o qual as figuras do mundo e o fundo do qual essas se destacam para a nossa percepção não podem ser concebidos. Bergson (1964, p. 51) na Evolução criadora chamou de corpo vivo esta individualidade cujas propriedades vitais nunca estão inteiramente realizadas, "estão sempre em vias de realização; são menos estados do que tendências". Tal corpo é, portanto, aberto ao tempo como experiência criadora do espírito humano que segue seu caminho "a par e passo do ato que o percorria, não sendo senão esse mesmo ato" (BERGSON, 1964, p. 83). Corpo em ato que atua um mundo, mais do que atua num mundo. Corpo autopoiético (MATURANA; VARELA, 1995) ou enativo, como prefere Varela (VARELA; THOMPSON; ROSCH, 2003).

Interessa-nos discutir a relação entre corporeidade e subjetividade no caso dos atingidos pela violência do Estado. Por corporeidade dos atingidos estamos designando a experiência que nos chegou à clínica em um grupo terapêutico que acolhia sujeitos que, de diferentes maneiras, mantiveram silenciada a vivência da violência.

Como clínicos, pudemos acompanhar os efeitos terapêuticos do testemunho público finalmente dado por uma de nossas pacientes, Maria de Fátima de Oliveira Setúbal, ${ }^{1}$ atendida por cerca de uma década por nós, enquanto membros da Equipe ClínicoGrupal do GTNM/RJ.

Fátima, mais recentemente, passou a frequentar as reuniões do projeto Clínicas do Testemunho, ligado à comissão Nacional da Verdade, visando preparála para prestar este depoimento, ao mesmo tempo em que permanecia em atendimento individual com um de nós (Cristina) depois de um logo período em que fora atendida no grupo terapêutico do GTNM em que nós dois éramos coterapeutas.

Escrever o relato de sua experiência de tortura com essa finalidade - a de prestar um depoimento no âmbito da Comissão Nacional da Verdade - foi uma experiência ${ }^{1} \mathrm{O}$ conteúdo desse texto foi discutido com Fátima Setúbal que autorizou que a identificássemos. 
perturbadora para a paciente, mesmo que ela estivesse acostumada a relatar as memórias desses fatos nas muitas sessões de psicoterapia grupal e individual a que se submetera ao longo de sua vida e também em reuniões de militância de direitos humanos. Enquanto se preparava para fazer seu testemunho, ela participou da reconstituição da morte de um de seus irmãos, promovida pela Comissão da Verdade e ocorrida numa vila do bairro carioca do Meier, 41 anos depois. Na reconstituição ficou finalmente esclarecido, com participação de moradores que prestaram depoimento, que não houve qualquer resistência por parte dos jovens que realizavam uma reunião da organização de esquerda Var-Palmares no interior de uma das casas. Além do irmão de Fátima, outras duas militantes ${ }^{2}$ foram executadas a tiros pela polícia, uma delas grávida, apesar de ter saído da casa de mãos para o alto. Foram momentos de muita emoção para Fátima, pois era a primeira vez que estava no local onde seu irmão morrera. Além disso, a própria escrita do depoimento a perturbava, e ela se lembra das razões que tinha para isso. Quando de sua prisão pelos órgãos da repressão, lhe foi também exigido que escrevesse um depoimento sobre o paradeiro de seus irmãos. Ela fora torturada para escrever e agora devia também escrever, dessa vez para denunciar publicamente, através de seu depoimento à comissão da verdade, as atrocidades de que fora vítima ao ser torturada aos 18 anos de idade. ${ }^{3}$

Contrariando e subvertendo essa proibição, ela consegue escrever o depoimento, com ajuda do projeto clínicas do testemunho. No mesmo período, é convidada pelo canal GNT, a participar de uma série na televisão, o seriado "Mulheres em Luta", exibido em 2014. Em cada um dos episódios, mulheres-militantes tinham suas histórias retratadas. Modificando inteiramente sua rotina, que consistia ultimamente em trabalhar na biblioteca de uma escola pública, ela está neste momento cheia de compromissos sociais ligados à militância e à organização desses testemunhos públicos, assim como à gravação da série televisiva. Nessa efervescência, ela conhece um escritor e também militante por quem se apaixona. Nossas sessões finais, em que preparávamos sua alta, discutíamos essa paixão, e alegria de sair pela primeira vez do Brasil, em viagem à Argentina, para receber um prêmio que fora concedido ao episódio da série do qual fora protagonista.

Em que esse período é diferente dos anteriores, nos quais ela relatava monotonamente sua história aos diferentes terapeutas que teve? No grupo terapêutico, a repetição das histórias de seu passado, da tortura que sofrera, vista a partir de um ângulo queixoso, tornava-se por vezes enfadonha para o grupo, que lhe cobrava que saísse dessa postura, e realizasse mudanças em sua vida, que se encontrava, sob diversos aspectos, paralisada. Sua fala no grupo podia ser vista também como uma

\footnotetext{
${ }^{2}$ Marcus Pinto de Oliveira, Maria Regina Lobo Leite de Figueiredo e Ligia Maria Salgado Nóbrega. Estes foram os três militantes executados pela polícia no episódio que ficou conhecido como a "chacina do Meier", sendo que Ligia estava grávida de dois meses.

${ }^{3}$ Fátima, como todas as mulheres presas políticas neste período, foi torturada nua. Foi colocada no pau de arara, sofreu choques, afogamento e enforcamento simulado (SETÚBAL, 2013).
}

espécie de ritual, no qual buscava salvar seus irmãos do esquecimento. Que todos conhecessem Marcus e Janu, ${ }^{4}$ sua história, suas lutas. Ela contava e recontava suas histórias quase com as mesmas palavras, enquanto sua vida pessoal permanecia rodando em círculos. Reconstituir o passado, nos diz Nietzsche, pode nos levar a criticar o presente encontrando forças para construir o futuro, mas pode também nos levar a cultivar a doença do ressentimento, a culpa e a mortificação, o que acaba nos levando à incapacidade de agir.

Fátima relatava a tortura que sofrera, e como sobrevivera, mediante um artifício no qual promete, durante as sessões de tortura, revelar "o ponto" no qual estaria um de seus irmãos. O local era a casa de um militar de alta patente que ela conhecia através de sua família. Levada no camburão à frente da casa, ela grita por socorro desesperadamente. Mediante essa estratégia, que demonstra sua coragem e lucidez apesar de ser tão jovem, ela acaba por ser transferida por seus algozes para o Hospital Central do Exército a pedido desse militar, o que acabou salvando sua vida. No grupo terapêutico, no entanto, ela não se apresenta como militante. Era apenas a "igualzinha entre os iguais", uma expressão criada por um amigo que dizia respeito à impressionante semelhança entre ela e os irmãos mortos.

Este fora um tema que abordamos muitas vezes em nossas sessões de terapia de grupo. As mulheres do grupo em geral não se descreviam como militantes. Por que não se viam como tal, preferindo falar dos irmãos, mortos ou vivos, ou de um pai ou marido militante? Parecia-nos que para elaborar suas vivências traumáticas, deveriam preferencialmente assumir que aquelas lutas de que participaram ao lado de seus familiares e cônjuges eram também suas. Mas geralmente as mulheres se viam como participantes secundárias, colaboradoras, simpatizantes ao mesmo tempo em que seu desejo e envolvimento na luta era negado. Para Françoise Sironi (1999) esse é um ponto central em sua clínica: a militância é um caminho para a elaboração e para cura. Seria preciso dizer: sim, eu estava na militância, tinha esse projeto, lutava por isso e por isso fora presa e torturada! Nossa paciente fora torturada principalmente para revelar o paradeiro dos irmãos, isso é certo, mas foi presa quando estava atuando pela mesma organização que eles, alfabetizando crianças em um subúrbio do Rio. No entanto, esse reconhecimento, de que também ela era uma militante e não apenas irmã dos militantes, igualzinha entre os iguais, só foi possível a partir de seu tratamento.

Nossa experiência indica que a melhora no tratamento é dificultada se a pessoa atingida pela violência institucionalizada sente como se o que sofreu fosse obra do acaso, do azar, do fato de estar junto com um familiar mais importante ou com um líder, ele sim, o militante, ou ainda negando inteiramente tudo o que fez naquela época, alegando ter esquecido o que se passou ou desvalorizando a própria luta. Como dissemos, verificamos que com frequência as mulheres se veem como uma espécie de dublê, como alguém que apenas fez de conta que era ${ }^{4}$ Januário Pinto de Oliveira 
militante. Isso pode dizer respeito não apenas à militância, mas a uma posição geral diante da vida, na qual se veem, não como donas de suas vidas, mas como coadjuvantes. Mais difícil a resolução de dificuldades nesses casos, em que a vida não é vivida em sua própria autoria. De que autoria estamos falando? Não se trata de uma autoria que diga respeito a um eu, mas à autonomia, numa certa concepção spinozista que aqui desenvolveremos.

Spinoza (2008, E III, 6, p. 173) utiliza a expressão "estar em si": "cada coisa esforça-se, tanto quanto está em si, por perseverar em seu ser" para se referir a um estado em que somos capazes de agir e de pensar melhor, em que somos mais potentes. Spinoza só usa a palavra agir quando essa ação decorre da "essência atual", como expressão da potência singular de cada indivíduo. Por outro lado, Spinoza utiliza a palavra paixão para se referir ao que fazemos quando estamos dominados por causas exteriores. Mas esses processos não são binários e excludentes, mas dizem respeito a uma correlação complexa de forças - a expressão "tanto quanto possível" aparecerá no texto de Spinoza para designar essas condições. Agimos, tanto quanto possível, a partir de nossa essência atual, ou seja, apesar das forças externas contrárias que quase sempre agem sobre nós. No Tratado Politico (SPINOZA, 2009, cap. II, 9, p. 91), o filósofo utiliza a expressão "estar sob a jurisdição de si mesmo" que tem um significado análogo, dessa vez mais referido à luta política. Mas para Spinoza não há diferença significativa entre a luta individual e a luta política: ambas dizem respeito à afirmação do conatus, que implica sempre em resistir a potências exteriores, que se forem maiores do que as nossas, podem sempre até mesmo nos destruir. Tanto os indivíduos quanto os povos podem ser dominados a partir do exterior, deixando de estar "sob a jurisdição de si próprios", quando se tornam escravos e passam a "ser do vencedor" (SPINOZA, 2009, cap. V, 6, p. 45). Porém quando estão sob a jurisdição de si próprios, podem repelir os invasores e reconquistar sua autonomia. Estar em si, estar sob a jurisdição de si mesmo, são, portanto, expressões que dizem respeito a um agir ativo e autônomo pelo qual deveremos lutar. Uma luta na qual não há uma vitória definitiva e para a qual estamos mais preparados se estamos no coletivo. $\mathrm{Na}$ afirmação de nossa autonomia, estamos sempre nos defrontando com forças que, agindo do exterior ou que se tornaram interiores, agem como forças contrárias, dificultando ou atrapalhando esse processo. Contra elas não há vitória garantida, apenas um embate constante e sem tréguas. Lutar, de forma independente do resultado, uma vez que o conatus não tem em si mesmo finalidade, mas lutar com prudência.

Detenhamo-nos um pouco na noção de prudência desenvolvida por Spinoza: uma prudência pensada a partir da potência e não a partir da obediência ou do medo. A prudência assim concebida não diz respeito ao medo, ou apenas à calculada espreita dos perigos que nos ameaçam, buscando antecipá-los, mas à própria potência do conatus, que possui nela mesma uma sabedoria que orienta, do interior da própria luta, a construção das melhores estratégias para sua afirmação (BOVE, 2012).

No percurso desse grupo terapêutico do qual tratamos neste artigo, a publicação de um livro foi uma importante ferramenta para que outra de nossas pacientes pudesse ter acesso à autoria de sua vida. Ela tivera vários casamentos durante sua juventude, casamentos com homens famosos e admirados. Apesar dela própria também ter tido uma carreira profissional que poderia lhe conferir também esse lugar de "mulher admirada", não se sentia como tal. Sentia-se como já suficientemente contemplada pela sorte ao ser admitida como companheira daquele homem ilustre e admirado, ou como participante do grupo de amigos do pai, todos eles militantes comunistas veteranos. Já era muita sorte... e essa posição a levava, não raro, a suportar situações em que era desprezada, tratada como subalterna, não merecedora das mesmas regalias que só os seres importantes (geralmente homens) merecem.

Uma terceira paciente fora particularmente marcada pelas experiências traumáticas que viveu quando estava atuando numa organização no Chile, nos momentos que precederam a queda de Salvador Allende. As experiências que viveram ainda estavam presentes, não eram passado para ela, pois ainda se conduzia como clandestina, a deslizar pela vida diária de modo furtivo, desaparecendo o mais rapidamente possível, como se corresse para um esconderijo. Anos depois, de volta ao Brasil depois de longo exílio, seu marido se tornara um bem-sucedido profissional, apesar das sequelas físicas da tortura que sofrera no temido Estádio Nacional em Santiago do Chile. Um fato ocorrido numa das sessões do grupo terapêutico nos ensinou que para ela, o tempo não passara. Foi perguntada por um companheiro de grupo o nome da organização a que pertencera e a pergunta foi sentida por ela como invasiva o suficiente ao ponto de preferir deixar o grupo. Havia segredos relativos à ação política que realizara há mais de quarenta anos que ela iria levar para o túmulo, mesmo depois do fim da ditadura militar e mesmo naquele grupo, no qual todos tinham tido algum tipo de experiência direta com a repressão naquele período. A partir da pergunta fatídica, o grupo foi sentido por ela como um grupo de estranhos e possíveis delatores. Seguindo com um de nós em terapia individual, essa dinâmica de "deslizar e desaparecer o mais rapidamente possível" seguiu se atualizando, apesar de aos poucos se permitir falar bem mais de sua vida passada e de sua militância. Ocupada em escapar, ela não conseguia se posicionar em relação a vários aspectos de sua vida - no trabalho, geralmente desempenhava funções subalternas e aquém de sua capacidade. Também não conseguia questionar o afastamento do marido. Ultimamente viviam como estranhos, se falavam pouco, ele dedicava todo o tempo disponível ao trabalho. Aceitava passiva e burocraticamente sua vida tal como ela se desenrolava, talvez por não querer fazer barulho e com isso atrair a polícia que rondava as ruas. Esse foi o tipo de sobrevivência que conseguira ter, depois das torturas e perseguições que sofrera, antes de seguir para o exílio. 
Para ela, vir às sessões semanais conversar já era muito, no sentido de interromper por uma hora esse estado de fuga. Experimentava a constante ameaça de um passado que não passava como que inscrito definitivamente em seu corpo que revivia mais do que vivia. Embora em seu corpo físico não pudéssemos identificar as marcas desse passado, sua experiência corporal a mantinha em contínua atitude de fuga - uma fuga que não a levava a deixar passar o que se passara.

A percepção de que a prisão e a tortura foram consequência da luta política em que os participantes do grupo estiveram engajados foi, em muitos casos, uma conquista do processo terapêutico. Embora pareça óbvio, tal elo fora perdido por eles. Em alguns casos, aquele período fora vivido como obra do acaso, do azar. As lutas empreendidas por eles tinham sua importância negada, ou tinham sido relegadas ao esquecimento por eles próprios, sendo as experiências de violência vividas no período da repressão as que com mais frequência permaneciam vivas na memória.

Quando passaram a ser concedidas pelo governo indenizações aos familiares de mortos e desaparecidos, pela lei 9140 de 4 de dezembro de 1995 (GRECO, 2003, p. 397) há um fato insólito que merece uma reflexão clínica: para obter as indenizações, os familiares deveriam, eles próprios, fazer prova de que o familiar estava morto, ou desaparecido. Quase duas décadas antes, na chamada "anistia parcial de 1979", chegou a ser criada uma "declaração de ausência" (GRECO, 2003, p. 299) a ser fornecida também pelo familiar, documento que significativamente assinalava outra ausência: a de qualquer esclarecimento oficial por parte do Estado sobre o paradeiro de seu ente querido. O Estado brasileiro recusava-se a admitir que havia torturado e matado, em muitos casos criando versões inteiramente fantasiosas, de que que teria havido confrontos armados, omitindo-se o fato de que tais confrontos, mesmo quando acontecidos, se davam em total desproporção de forças. Ao fazer isso, implicitamente, o Estado considerava que os mortos e desparecidos ou os militantes eram únicos responsáveis por aqueles episódios e igualmente os únicos culpados por suas consequências, prevalecendo a lógica da Segurança Nacional que estes haviam supostamente ameaçado. Não havia documentos oficiais que pudessem comprovar os atos de lesa humanidade praticados pelo Estado brasileiro. Os fatos violentos ocorridos estavam referidos apenas a eles, suas "vítimas". Não é de se estranhar que o elo entre as lutas políticas e suas consequências (a repressão sofrida) tenha se perdido para muitos militantes, uma vez que o que se procurava encobrir era a existência mesma de uma luta política e as razões dessa luta, com pelo menos dois protagonistas, sendo um deles o Estado. O Estado violador se volta contra seu próprio povo, ao invés de defender seus interesses e anseios. O Estado buscava encobrir as razões dessa luta, que expressavam justamente a capacidade de resistência de um povo.

Utilizamos a palavra vítima, colocando-a entre aspas, já que essa não era para nós da equipe Clínico-Grupal Tortura Nunca Mais uma boa palavra para designar nossos pacientes, justamente porque deixava encoberta a luta política por eles travada. A palavra vítima talvez caiba para designar alguém que sofre uma lesão num acidente de trânsito ou numa catástrofe natural, mas não é cabível para designar um guerrilheiro, um militante, um membro de um partido político, alguém engajado numa luta política e que em consequência da mesma sofreu repressão por parte do Estado. Preferimos a palavra "atingidos" pela violência do Estado, que nos parece apontar para a história dessas lutas, que eram as lutas do povo brasileiro por uma sociedade mais justa e mais livre e que tornavam seus sofrimentos consequência do modo como o Estado brasileiro daquele período reprimiu e pretendeu extinguir essas lutas e seus protagonistas, Estado esse dissociado dos anseios de seu povo e servindo a interesses alheios a muitos brasileiros.

Podemos nos perguntar se essa percepção - a de estar ou ter estado numa luta - é suficiente para produzir elaboração psíquica. Seria preciso ter sido vitorioso? Para alguns participantes do nosso grupo terapêutico, a vitória traria saúde, enquanto a derrota faria naufragar na doença. Questionamos, no grupo, este ponto de vista, considerando que perceber a derrota pode estar ligado à saúde. Tomar o ponto de vista da luta, independente do seu resultado, isso nos parecia ser o mais importante. Neste sentido, podia ser importante reconhecer a derrota. Quando lutamos por algo, corremos o risco da vitória, da derrota, de nossa destruição total, e de todos graus intermediários entre essas duas situações: derrotas parciais, vitórias parciais, que podemos deixar de perceber.

Em nosso grupo terapêutico, uma discussão sobre reconhecer a derrota foi importante. Permitiu ultrapassar um sentimento de fragilidade, de covardia, de fracasso, que costumava atacar mais aos homens, segundo pudemos perceber somente agora, ao escrever esse artigo. Um de nossos pacientes era alguém cuja vida fora marcada por ter sido o "causador" indireto da morte de seu pai. Ele estava respondendo a um processo na justiça militar e o pai viera de carro para o julgamento, de uma cidade distante. $\mathrm{Na}$ estrada, morrera num acidente. A saída para esse paciente, que só nos trouxe essa história quando perguntado no grupo sobre o período de sua militância, fora negar que algum dia tivesse sido um militante. Costumava dizer que nunca fora um militante, que era jovem demais ... É como se dissesse: "eu hem? Não tenho nada com isso". Ele não queria ser acusado pela morte do pai, embora deva ter sido, por ele próprio e por outras pessoas de sua família. Os detalhes dessa história, os sentimentos por ele vividos ele nunca os trouxe para discussão no grupo, o qual deixou abruptamente pouco depois de nos contar esse episódio dramático da morte do pai.

Pensávamos que mais interessante, mais útil do ponto de vista de uma vida potente, seria não negar a militância que um dia praticara. De fato, esse paciente tinha uma vida despotencializada, ao nosso ver. Participava de uma seita religiosa com características sectárias e levava uma vida solitária. O grupo discutiu longamente, na última sessão de terapia da qual participou, sobre a derrota que a esquerda sofrera nos anos da ditadura. 
Ser derrotado numa batalha é um sentimento diferente de ser humilhado, desautorizado, de se considerar e ser considerado um covarde, um fracassado, ou culpado, ou ainda de ser inconsequente e infantil. A derrota não estingue a possibilidade de vitórias futuras, enquanto o sentimento de impotência, de fracasso, de covardia pode nos incapacitar para seguir lutando. No entanto, esse paciente insistia na recusa da derrota. Defender que não havia sido derrotado o afastava daquela luta, o afastava dos companheiros de luta, o afastava do grupo terapêutico. A corporeidade em fuga se mostrou como um fenômeno clínico-político importante na experiência desse grupo terapêutico.

Outro paciente nosso vivia intensamente um sentimento de ter perdido sua capacidade de trabalho e liderança. Desvalorizava o que conseguia realizar em seu trabalho atual, ao qual se dedicava muito, no serviço público, com um sentimento de que nada valia à pena. Com o fracasso de um empreendimento anterior, em sociedade com a ex-esposa, contraíra muitas dívidas e teve que baixar muito seu padrão de vida, indo morar depois de separado com uma irmã idosa. Esse paciente pertencera a uma organização de esquerda e fora preso e torturado. Ao sair da prisão, a orientação política do partido mudara e ele se viu sozinho, com um sentimento de que lutara inutilmente, já que aquelas lutas, no momento de sua saída da prisão, tinham sido abandonadas pela própria organização. Esse sentimento de solidão ele carregava em tudo o que fazia, e tinha dificuldade de construir estratégias de trabalho coletivas, o que o deixava muito sobrecarregado no trabalho. Essa sobrecarga afetava sua saúde. Com o trabalho terapêutico do grupo, ele parece ter encontrado o fio que ligava seu trabalho atual com as lutas políticas em que sempre se envolvera. Essas lutas não se esgotavam na organização que o decepcionara, pois não tinham deixado de existir nele. E ele pode retomá-las de outra forma, dessa vez construindo uma vida bastante singular, na qual o trabalho-militante que realizava se fortaleceu, assim como sua vida amorosa, apesar dos muitos problemas diários que a falta de dinheiro lhe trazia, pois destinava grande parte do seu salário ao pagamento de dívidas. Durante o processo terapêutico, ele reencontrara uma antiga paixão pela internet, uma namorada que tivera quando morara nos Estados Unidos no final dos anos sessenta, em plena efervescência contracultural das lutas por direitos civis e contra a guerra do Vietnam. Ao reconectar-se com o fio que o ligava a essas lutas do passado, pode reconectar-se também com o sentido se sua militância de hoje, daquela que empreendeu durante a ditadura miliar, e com os diversos modos de ser militante que povoaram sua vida.

Outra de nossas clientes era uma jovem, filha de um militante. Ela viveu sua infância quando seus pais se encontravam na clandestinidade. Enquanto o pai e mãe militavam, ela cuidava dos irmãos menores, chegando a ser treinada sobre como pular o muro das diferentes casas em que viveram, caso fosse necessário fugir da polícia. Mais tarde os pais se separam e a dependência dos irmãos para com ela e suas responsabilidades de mãe substituta se ampliaram. Ela acompanhava as sessões num choro silencioso, lágrimas escorrendo pela face. Por que chora? Não sabe dizer. Chora por tudo! Pelas experiências narradas no grupo, semelhantes às suas. Por tudo o que não chorou em sua infância, no tempo em que talvez isso lhe fosse franqueado de direito. Afinal, criança chora! Mas ela não pôde - teve que viver momentos de tensão cuidando dos irmãos menores, sempre usando um sobrenome falso na escola, se mudando de cidade, sempre mudando de casa e tendo que aprender a fugir pulando o muro. Era difícil ter uma vida de criança que pode chorar. A clandestinidade dos militantes e suas famílias se inscrevia no corpo vivo como um órgão do silêncio. O corpo biomecânico é capaz de falar, mas a corporeidade em fuga deve se manter no silêncio. No caso dessa paciente que desde menina apreendera, na intensidade da luta cotidiana, a não falar quem era, o silenciamento se mantinha como uma barreira corpórea. Aprendera a pular o muro assim como a silenciar: formas complementares dessa fuga para lugar nenhum, fuga que a mantém presa no território de medo do qual tenta escapar. Escapa indefinidamente sem que chegue a traçar uma linha de fuga que lhe permita perspectivar de outra maneira sua vida. No grupo terapêutico ela chorava a cada vez que era convocada a dizer mesmo a mais simples trivialidade de sua vida. Qualquer relato íntimo, mesmo uma banalidade de seu cotidiano, disparava nela esse choro que reagia à experiência de abertura, de quebra do silêncio. Em sua corporeidade persistia o imperativo de resistir e não abrir: eis a palavra de ordem que se incorporava naquelas existências. No vocabulário da militância contra a ditadura no Brasil, abrir significava trair, delatar, comprometer a integridade não só do movimento de resistência à ditadura, como também, e sobretudo, a integridade física dos companheiros. Não se podia abrir. Um dos elementos que nossa clínica nos ensinou foi que a vida na clandestinidade, a perseguição política e o fato de ter que viver tudo na solidão e em segredo constituem, como poderíamos designar, um "agente patogênico" importante. Esse caso extremo, a que acabamos de nos referir, dizia respeito a várias proibições e limitações em relação ao contato social que eram impostas à nossa paciente, quando criança: a proibição de usar seu próprio sobrenome, o fato de se mudar sempre e isso dificultar fazer amizades com outras crianças na localidade em que vivia, tudo isso justificado pelo fato de que o pai realizava uma atividade importante junto a uma organização clandestina que deveria ser mantida em segredo.

Desde Freud, sabemos que as proibições produzem efeitos traumáticos, mas esse tipo de proibição é diferente daquela imposta à sexualidade, vista por Freud como determinante da neurose. A palavra proibição aqui se aplica a outros conteúdos: a manter em segredo a identidade da família, e a sua própria, a estar sofrendo uma perseguição, a não saber se será levado preso, ou se irá sobreviver. Talvez a palavra silenciamento seja mais adequada para descrever as circunstâncias vividas por muitos militantes em situação de clandestinidade. Talvez 
ela descreva melhor a sensação de ameaça permanente, e de não ter a quem recorrer, frequentemente associada ao sentimento de que esse seu drama não importa ou não é compreendido pelas outras pessoas. Silenciamento talvez seja uma palavra mais adequada para descrever a percepção de que a sociedade não se importa com o que acontece consigo próprio e com sua família, que não consegue compreender as razões de sua luta, que aliás, é a luta de um povo. Corporeidade em silenciamento.

As mortes, os desaparecimentos, ou no caso dos atuais assassinatos de jovens pretos, pardos e pobres perpetrados por policiais - as famílias das vítimas desse tipo de violência percebem que não há interesse da sociedade com relação com o que se passou com eles, e essa percepção produz fortes sentimentos de menos valia, entre outros afetos tristes, que implicam em despotencialização subjetiva. Podemos, portanto, ampliar nossa concepção de trauma, incluindo outros tipos de acontecimento para além do sexual entre os que podem ser agentes traumáticos. Abrindo mão de "ideias gerais" "na definição do traumático, podemos incluir, na compreensão desses processos, a vida vivida em fuga, em silêncio, no isolamento, em segredo, a vida na qual as relações com o coletivo estão restritas a um mínimo. Para Spinoza, a solidão caminha no sentido inverso ao da saúde, razão pela qual ele considera a democracia da multidão como saúde. Há todo um elogio do coletivo na obra de Spinoza (2008, IV, 35, corolário I), ao dizer que nada há de mais valioso para um homem do que um outro homem. Na solidão experimentamos um grau de potência, mas ele se torna inoperante ao tornamo-nos com mais facilidade tristes. Na tristeza experimentamos graus menores de nossa potência, o que quer dizer que pensamos e agimos pior do que se estivéssemos no coletivo. Eis uma das razões para fazermos também, enquanto terapeutas, um elogio do grupo terapêutico, ou do quão terapêutico pode ser um grupo, uma vez que todo indivíduo é uma multidão, pois é composto de múltiplos indivíduos. No grupo terapêutico que realizamos éramos uma multidão, cada um de nós era uma multiplicidade, e nessa multiplicidade de agenciamentos que ali se estabeleceram repousou seu caráter terapêutico. Isso não quer dizer que tenhamos podido acionar toda a potência de transformação existente no grupo em todos os momentos, embora em alguns, sem dúvida, isso tenha se dado. Na clínica grupal de inspiração spinozista, nada está garantido, mas também, nada está perdido, pois é sempre possível acionar a potência da multidão ou a "grupalidade", no sentido dado por Antônio Lancetti (1993).

Um desafio da clínica no contemporâneo é o de realizar a desprivatização e desintimização de seus dispositivos de intervenção. Neste sentido, o dispositivo grupal intensifica a interface entre a clínica e a política, problematizando o modo indivíduo de subjetivação na nossa sociedade (BARROS, 2007). A dimensão do

\footnotetext{
${ }^{5}$ Aqui nos referimos à crítica das ideias gerais ou universais feita por Spinoza, para quem não existem "o bem" ou "o mal", estendendo tal crítica à concepção genérica de trauma sexual. Já nos referimos a essa questão no livro Clínica do esquecimento (RAUTER, 2012).
}

coletivo não pode ser tomada como oposta ou separada da dimensão subjetiva, constituindo, de nosso ponto de vista, o plano de produção de efeitos de subjetividade. Acessar este plano é tarefa da clínica, sendo o grupo um dispositivo potente para tal. Na experiência com o grupo terapêutico do GTNM/RJ, verificamos o movimento de retraimento subjetivo expresso na corporeidade dos participantes, seja na forma do enclausuramento nos espaços privados, seja no esvaziamento dos espaços públicos, o que vinha relacionado a uma sintomática marcada pelo pânico, pela depressão. $\mathrm{O}$ enfraquecimento das experiências do coletivo marcava corporalmente aquelas pessoas, exigindo um esforço da clínica para acompanhar as modulações subjetivas resultantes tanto da experiência da violência do Estado quanto do processo de contração de grupalidade no dispositivo terapêutico.

A tortura visa muito mais fazer calar do que faze falar, e principalmente, individualizar, reduzir, desconectar a luta daquele indivíduo das lutas coletivas ou da grupalidade. Terrorista, subversivo e mais recentemente, vândalo, são categorias disseminadas para produzir essa dissociação. Por outro lado, produzindo medo e dor a partir dos espancamentos arbitrários, das tecnologias para causar sofrimento, das execuções sumárias, o Estado autoritário pretende desencorajar a adesão de outros, apesar de que a luta seja de todos os que vivem as mesmas condições de opressão, e por essa razão os afetos comuns estão sempre se dando. Os mecanismos de multiplicação por imitação e contágio têm sua ação reduzida a partir do medo produzido pela tortura e pelas mortes praticadas por agentes do Estado. No entanto, na multidão, ou nos grupos, é mais possível experimentar, por contágio, outros afetos que não os afetos negativos que contribuem para a despotencialização e para a desistência da luta. Eis uma das razões para acreditarmos nos grupos.

Por razões análogas, acreditamos que o esclarecimento dos crimes praticados durante a ditadura civil militar está também ligado a essa saúde que faria reconectar o Estado com seu povo e restituir o significado de suas lutas passadas e presentes. Pudemos verificar a importância clínica da experiência de coletivização do sofrimento seja no grupo terapêutico seja no depoimento à Comissão da Verdade quando este pode se realizar, por ultrapassar o silenciamento e possibilitar a reconexão com as lutas empreendidas por essa geração num passado não tão distante.

\section{Referências}

BARROS, R. B de. Grupo: afirmação de um simulacro. Porto Alegre: Sulina, 2007.

BERGSON, H. Evolução criadora. Rio de Janeiro: Delta, 1964.

BOVE, L. Spinoza et la question éthico-social du désir: études comparatives avec Épicure-Lucrece et Machiavel. Fractal: Revista de Psicologia, Niterói, v. 24, n. 3, p. 443-472, dez. 2012. Cross ${ }^{\text {Ref }}$

GRECO, H. A. Dimensões fundacionais da luta pela anistia. 2003. Tese (Doutorado)-Universidade Federal de Minas Gerais, Belo Horizonte, 2003. 
GUATTARI, F. As três ecologias. Campinas: Papirus, 1990.

LANCETTI, A. (Org.). Grupo terapêutico com psicóticos: a grupalidade que os especialistas não entendem. In:

SaúdeLoucura: grupos e coletivos. São Paulo: Hucitec, 1993. v. 4 , p. $148-166$.

MATURANA, H.; VARELA, F. A árvore do conhecimento. São Paulo: Psy II, 1995.

MERLEAU-PONTY, M. Fenomenologia da percepção. Rio de Janeiro: Freitas Bastos, 1971.

RAUTER, C. Clínica do esquecimento. Niterói: Eduff, 2012.

SETÚBAL, F. O. Depoimento à Comissão da Verdade na íntegra. Testemunho prestado perante à $\mathrm{CEV} / \mathrm{RJ}$ e à $\mathrm{CNV}$ em audiência pública. Rio de Janeiro, 29 out. 2013. Arquivo CNV, 00092.001880/2014-6329 out. 2013. Disponível em: <http:/ prosacaotica.blogspot.com.br/2013/11/depoimento-comissaoda-verdade-na.html>. Acesso em: 6 ago. 2017.

SIRONI, F. Bourreaux et victimes: psychologie de la torture. Paris: Odile Jacob, 1999.

SPINOZA, B. Ética. Belo Horizonte: Autêntica, 2008.

SPINOZA, B. Tratado Político. São Paulo: Martins Fontes, 2009.

VARELA, F.; THOMPSON, E; ROSCH, E. A mente incorporada: ciências cognitivas e experiência humana. São Paulo: ARTMED, 2003.

Recebido em: 17 de janeiro de 2017 Aceito em: 29 de agosto de 2017 